\title{
İlkokul İngilizce Öğretmenlerinin Kendi Yabancı Dil Yeterlikleri Hakkındaki Görüşleri ${ }^{1}$
}

\author{
Doç. Dr. Seval EMINOĞLU-KÜÇÜKTEPE** \\ Marmara Üniversitesi, Atatürk Eğitim Fakültesi, Eğitim Bilimleri Bölümü, İstanbul / Türkiye, \\ sevalek@marmara.edu.tr, ORCID: 0000-0003-0247-6654 \\ Ecenur Büşra GÜNEŞ \\ Akasya Koleji, İstanbul / Türkiye, \\ gunesecenur@gmail.com, ORCID: 0000-0003-0574-0043
}

\section{Öz}

$\mathrm{Bu}$ araştırmanın amacı ilkokul İngilizce öğretmenlerinin kendi dil yeterliklerine yönelik görüşlerini tespit etmektir. Araştırma ilkokul İngilizce öğretmenlerinin görüşlerini tespit etmek amacıyla karma yöntemde gerçekleştirilmiştir. Araştırmanın çalışma grubunu 2019-2020 eğitim öğretim yılında Türkiye'nin çeşitli bölgelerinde görev yapan ve çalışmaya gönüllü olarak katılan 117 ilkokul İngilizce öğretmeni oluşturmaktadır. Veriler araştırmacılar tarafından hazırlanan ve geçerlik için uzman görüşünden yararlanılan anket ile Google Forms aracılığıyla online olarak toplanmıştır. Elde edilen veriler SPSS 24 paket programı ile analiz edilmiş, yüzde ve frekans tabloları yardımıyla yorumlanmıştır. Araştırmanın sonuçlarına göre öğretmenlerin büyük bir çoğunluğu mesleklerine başladıktan sonra İngilizce dil yeterliklerinde fark görmektedir ve bu fark olumsuz yöndedir. Öğretmenlerin çoğu ders verdikleri kademenin yabancı dil yeterliklerine olumsuz etkisinin olduğunu düşünmektedir. Araştırmaya katılan

\footnotetext{
1 Bu araştırma IBAD-2020 kongresinde online bildiri olarak sunulmuştur.

* Sorumlu Yazar. Tel: +90 5365480471 | Araştırma Makalesi.

Makale Tarih Bilgisi. Gönderim: 17.11.2020, Kabûl: 14.05.2021, Erken Görünüm: 20.09.2021, Basım: Aralık, 2022

(C) 2022. Kalem Eğitim ve Sağlık Hizmetleri Vakfı. Bütün Hakları Saklıdır. ISSN: 2146-5606, e-ISSN: 2687-6574.
} 
öğretmenlerin büyük bir kısmı günlük hayatta İngilizceyi yabancı dizi ve film izleyerek geliştirmeye çalıştıklarını belirtmişlerdir ve birçoğunun okul dışında yabancı dillerini aktif olarak kullanma imkanları yoktur. Araştırmadan elde edilen diğer bir bulgu ise öğretmenlerin \%86.3'ünün eğer uzun ylllar ilkokul kademesinde İngilizce öğretmeni olmaya devam ederlerse bu durumun yabancı dil yeterliklerinde ciddi bir olumsuzluğa neden olacağını düşünmeleridir.

Anahtar Kelimeler: İlkokul İngilizce öğretmeni; Yeterlik; Yabancı dil yeterliği; Mesleki yeterlik.

\title{
Primary School English Teachers' Views on Their Foreign Language Proficiency
}

\begin{abstract}
The aim of this research is to determine the opinions of primary school English teachers about their own foreign language proficiency. The study was conducted as a mixed method and the data were collected through short written answers of teachers. The participants who took part in the study were 117 volunteer primary school English teachers. The obtained data were analyzed by SPSS Statistic 24 program and interpreted with the help of percentage and frequency tables. According to the results of the study, most of the teachers notice a difference in their English language proficiency after starting their profession, and this difference is negative. Also, teachers think that the grade they teach has a negative impact on their foreign language proficiency. Another finding of the study is that most of the teachers do not have the opportunity to actively use their foreign language outside of school. Moreover, $86.3 \%$ of teachers think that if they continue to be an English teacher at the primary school level for many years, this will cause serious negativity in their foreign language proficiency.
\end{abstract}

Keywords: Primary school English teacher; Foreign language proficiency; Professional competence; Efficacy.

\section{Extended Summary}

\section{Purpose}

There are studies which conclude that teachers perceive their language proficiency at a good level. On the other hand, there are also some studies which conclude that teachers experience problems with their language proficiency and this situation affects their lessons. In the literature review, it was seen that there is a limited number of studies that focus especially on primary school English teachers' language proficiency and change in that proficiency 
as the teachers progress in their profession. Studies in Turkey have generally been carried out within the framework of professional competences and competences for the students to gain and develop certain language strategies.

Moreover, teachers are one of the most important implementers of education programs. Teachers' professional competences are directly linked to the students' knowledge, skills, attitudes and values that are tried to be gained as teachers' perceptions of self-efficacy can affect the quality of education. For this reason, teachers need to gain awareness of their competences in their field in terms of education programs.

Therefore, this study aims to investigate opinions of primary school English teachers about their own proficiency in English. In line with this general purpose, answers to the following questions were sought:

1. What are the activities of primary school English teachers for foreign language development outside of school?

2. What are the opinions of primary school English teachers about:

1. Their foreign language proficiency after starting their profession?

2. The effects of the age group or grade that they teach on their foreign language proficiency?

3. The effects of foreign language development activities outside of school on their teaching activities?

4. The effects of working time at a primary school level on their foreign language proficiency?

\section{Method}

The study is a mixed method research that aims to describe the current situation of primary school English teachers' opinions about their foreign language proficiency through their written answers. Participants of the study were 117 primary school English teachers who are working in different cities of Turkey in the 2019-2020 academic year. To collect data, a questionnaire was prepared by the researchers. During the process of preparing this questionnaire, opinions of two experts from Educational Sciences and English Language Teaching were taken into consideration to ensure validity. Upon the comments of experts, questions were rearranged. The questionnaire was shared with the teachers via social media and the answers of volunteer teachers were evaluated. To analyze data, researchers used SPSS Statistic 24 program. 


\section{Results}

While $73.5 \%$ of the teachers participating in the research think that the level they teach has an impact on their foreign language proficiency, the rest $(26.5 \%)$ do not think of any effect. $85.5 \%$ of the teachers who think there is an effect mentioned that this effect is negative. On the other hand, teachers who think that the primary school level has a positive effect on their language proficiency stated that they had to adapt their language to reach the student level, so they became more specialized at the primary school level.

Most of the primary school English teachers indicated that they improved their English in daily life by watching foreign TV series and movies. $23.3 \%$ of the teachers stated that they focused on reading activities such as novels, books, articles in the original language of English. 10.1\% of the teachers pointed out that they aim to keep their reading and listening skills alive by following the channels broadcasting in English, websites that prepare content for English learners and similar applications through social media.

The majority of teachers $(70.9 \%)$ cannot find an opportunity to use their foreign language outside of school. On the other hand, teachers who have this opportunity can do that with their own efforts.

While $52.9 \%$ of the teachers who use English outside of school thought that this effect was positive, no one thought it had a negative effect. Approximately $9 \%$ of the teachers stated that out-of-school language activities had no effect on their lessons or teaching.

While $24 \%$ of the teachers who do not have the opportunity to use the English language outside of school think that this situation affects their teaching negatively, none of the teachers stated that the effect was positive. Approximately $23 \%$ of the teachers do not think that not using English outside of school has any effect on their teaching.

$86.3 \%$ of English teachers in the study stated that if they continue teaching at this level for many years, they will experience a serious negative effect on their foreign language proficiency. The common thoughts of teachers who have this view are that they will experience regression and dullness in their foreign language. These teachers pointed out that they could not remember many language structures and knowledge they knew before. 


\section{Discussion}

According to the findings obtained from the research, it was revealed that a great majority of the participating teachers saw a difference in their language proficiency after starting their profession. Another result is that an important part of the teachers stated that this difference is negative. It is observed that teachers experienced a regression in their foreign language proficiency and they attribute this to teaching at a primary school. Teachers complain that they speak English at a limited level by constantly using the same language patterns.

Most of the teachers stated that they carry out their extracurricular foreign language activities with their own efforts, independent of the institution or ministry they work for. Besides, there was no difference between the years spent by teachers in their profession and the change in their language proficiency. It was revealed that many teachers who are still at the beginning of their professional experience believe that having regression in English will increase in the coming years.

Primary school English teachers' opportunities to use their foreign languages in daily life are quite limited. The fact that teachers are only exposed to limited language use in lessons and that they do not have the opportunity to keep their language alive are important findings that should be examined in the field.

The research was generally carried out with teachers working in public schools, and teachers working in private schools also stated that there are negative differences in their foreign language proficiency.

\section{Conclusion}

Based on the findings of this research, it is suggested that instead of working at primary school for many years, teachers can be directed to a change in grade after a certain year. In future studies, research can be done with quantitative and mixed methods.

\section{Giriş}

İnsanoğlu dünyada var olduğu ilk andan itibaren günümüze kadar sürekli olarak bilgi üretmiş ve çeşitli buluşlar meydana getirmiştir. Tüm bu buluşlar toplumları etkilemiş ve çağları yönlendirmiştir. Her çağda belli bir olgu ön plana çıkmış, toplumun ihtiyaçları ve yaşayış tarzı bu olgu etrafında oluşmuştur. Örneğin matbaanın icadı ile bilgi üretiminde artış yaşanmış ve bilgi 
ulaşılabilir hâle gelmiştir. Bilginin yaygınlaşması toplumsal reformları beraberinde getirmiş, toplumun değer yargılarında değişiklikler oluşmuştur. Sanayi devrimi ile birlikte tarım toplumunun yerini sanayi toplumu almış, makine gücü ve maddi değerler ön plana çıkmıştır. Buhar gücü ile çalışan makineler sayesinde üretimde artış meydana gelmiş ve sermayeye ihtiyaç duyulmuştur. Fabrikaların artması, köy yerleşiminden kent yerleşimine geçilmesi gibi önemli sosyolojik ve ekonomik değişimler de sanayi toplumuna geçişin ürünleridir.

Günümüzde ise bilgi güçtür. Gelişen teknoloji ile beraber insan ihtiyaçları değişmiş ve bilgi üreten güçlü hâle gelir olmuştur. Ancak çok fazla üretilen bu bilginin nitelikli olanını bulabilme ve gerekli elemeleri yaparak doğru bilgiye ulaşmak için bireyler birtakım düşünme becerileri ile donanmış olmak zorundadır. Toplumda meydana gelen bu değişmeler, eğitime de yansımış ve artık "öğrenmeyi öğrenme” durumu gerekli olmuştur. Görüldüğü gibi toplumsal her değişim eğitimi de etkilemekte, eğitimdeki her değişiklik de topluma yansımaktadır. Çünkü toplum ve eğitim iç içedir. Bir başka deyişle, ülkelerin ekonomik, sosyal, kültürel, bilimsel ve teknolojik alanlarda ilerleyebilmesinde eğitim oldukça önemlidir. Bireylerdeki davranışların değişiminde en büyük rollerden birine sahip olduğu düşünülen eğitimin gelişimi, öğretmen niteliğinin gelişimi ile doğrudan ilişkilidir ve bu durum yetiştirilen bireylerin niteliğini de etkilemektedir (Demirel, 1989). Bu nedenle eğitim sisteminin kilit rollerinden birisi olan öğretmenlerin de meslekleri ile ilgili bazı yeterlikleri kazanmış olmaları istenmektedir (Yeşilyurt, 2011). Öğretmenler toplumsal gelişimi ve ilerlemeyi sağlarken bir yandan bu değişimi sağlayacak bireyleri de yetiştirmektedirler (Kararmaz ve Arslan, 2014). Bu nedenledir ki öğretmen yeterlikleri ile toplumsal gelişim arasında sıkı bir bağ vardır. Çünkü öğretmenlerin yeterlikleri ne kadar yüksek düzeyde olursa öğrencinin ve öğrenmenin niteliği de bu oranda artacaktır (Karacaoğlu, 2008). Öğretmenlerin niteliği ise birçok unsurdan oluşmaktadır. Bu unsurlardan biri öğretmenin görev yaptığı branşta yeterli bilgiye sahip olması ve bu bilgiyi aktarabilme becerisidir. Karacaoğlu'na (2008) göre, öğretmenden beklenen; kendi öğretim alanı ile ilgili bilgileri iyi bilmesiyle beraber, öğrenme sırasındaki güçlükleri ortadan kaldırma, grup çalışmalarını organize etme, öğrencilerin dikkatini canlı tutabilmesidir. Buradan anlaşılacağı üzere, bir öğretmenin ders verdiği alanda zaten uzman olduğu varsayılmakta ve artık günümüze uygun başka becerileri kazandırmasına önem vermesi beklenmektedir. Ancak öğretmenlerin birçoğu kendi öğretim alanı ile ilgili sorunlar yaşamaktadır. Bu alanda sorun yaşayan 
branşlardan biri de İngilizce öğretmenleridir. İngilizce öğretmenleri, öğretim sırasında mesleki gelişim açısından yetersiz hissetmelerini karşılaşılan bir zorluk olarak görmektedirler (Songbatumis, 2017).

Ülkemizde öğrencilere İngilizce dil yeterliği ve konuşma becerisi kazandırma konusunda sorunlar yaşanmaktadır. British Council ve TEPAV'ın Türkiye'deki devlet okullarıyla gerçekleştirdikleri çalışma raporunda, öğrencilerin yaklaşık 1000 saatten fazla sınıf içi ders almalarına karşın liseden mezun olurken İngilizceyi konuşup anlamakta başarısız oldukları belirtilmiştir (Özen ve ark., 2014). Öğrenciler açısından durum böyle iken öğretmenler için bu durum farklı mıdır? Bu dilin öğreticisi ve uygulayıcısı olan öğretmenlerin kendi dil becerileri yeterli düzeyde midir? Ne yazık ki öğretmenler de öğrettikleri yabancı dil yeterliğinde ciddi sıkıntılar yaşamaktadır ve bu sıkıntılar bir an önce çözülmelidir. Çünkü öğretmenlerin yeterlikleri mesleki bilgilerinde ve genel kültür düzeylerinde olduğu kadar, öğrettikleri alanın bilgisiyle de yakından ilişkilidir (Yeşilyurt, 2013). Örneğin, Millî Eğitim Bakanlığı (2017) tarafından hazırlanan, Öğretmenlik Mesleği Genel Yeterlikleri çalışmasında; bir öğretmenin, alanında sorgulayıcı bakış açısını kapsayacak şekilde ileri düzeyde kuramsal, metodolojik ve olgusal bilgiye sahip olması gerektiği belirtilmiştir. Daha özele inildiğinde ve bu yeterlikler İngilizce öğretmenleri açısından değerlendirildiğinde bir İngilizce öğretmeninin alanı olan dilde gerekli bilgiye sahip olması tüm öğrenme - öğretme sürecinin planlanmasında etkin bir rol oynamaktadır. Yine Millî Eğitim Bakanlığı tarafından hazırlanan İngilizce Öğretmeni Özel Alan Yeterlikleri (2015) raporunda, İngilizce öğretmenlerinin, İngilizceyi akıcı ve doğru kullanmada öğrencilerine model olmaları beklenmektedir. Benzer şekilde Lange (1990), dil yeterliğinin anadili İngilizce olmayan İngilizce öğretmenlerinin meslekteki güven duygularının belli başlı unsurlarından birisinin olduğunu ve bu yeterliğin iyi bir dil öğretmenliği için en gerekli kriterlerin başında geldiğini söylemiştir (akt; Eslami ve Fatahi, 2008, s.5). Özellikle dil öğretiminde öğrencilerin dile maruz kalmalarını sağlayacak en önemli kaynaklardan biri öğretmenlerdir. Öğretmenlerin sınıf içerisinde kullandıkları dil, öğrencilerdeki dil girdilerinin artmasına yarar sağlamaktadır. Ayrıca alanında gerekli yeterliğe sahip olan bir İngilizce öğretmeni, dilin farklı kullanım amaçlarına yönelik dersler planlayabilir ve öğrencilerinin dildeki gelişim sürecini takip edebilir. Bu nedenle İngilizce öğretmenlerinin mesleklerinde yeterli hissetmeleri öğrettikleri dilde uzmanlaşma ve öğretim stratejilerine hakim olma ile doğrudan ilgilidir (Yılmaz, 2011). Öğrettikleri alanda kendilerini yeterli görmeyen öğretmenlerin, öğretme süreçleri boyunca 
kendilerine karşı da güvensizlik yaşamaları kaçınılmazdır. Bu durumun öğretimlerine yansıması, daha etkin ve aktif öğrenme metotlarını kullanmalarını engellemektedir; çünkü İngilizce dilinde kendini yeterli görmeyen bir öğretmen sınıf içerisinde güvenli alanının dışına çıkmak istemeyebilir ve öğrenciler sinırlı bir dil üretimine maruz kalabilirler. Allen, Galaczi, Nye ve Poulter (2018) tarafindan öğretmenlerin mesleki gelişimleri ile ilgili hazırlanan raporda bu konudan şöyle bahsedilmektedir:

"Hem ögretmenlerden beklenen dil seviyesi ile gerçekte sahip oldukları dil düzeyi arasındaki kopukluğa yönelik farkındalık hem de ögretmenlerin İngilizce dilindeki yeterliklerini gelişstirmeleri için ihtiyaca yönelik farkındalık artmaktadır. Fakat tüm uğraşlara rağmen, özellikle gelişmekte olan ülkelerde ve kirsal bölgelerde görevli ögretmenler İngilizceyi işlevsel düzeyde kullanamamaktadırlar ve bu durum ögrencilerine etkin bir öğrenme ortamı oluşturmalarını güçleştirmektedir."

İlkokul İngilizce öğretmenleri açısından ise durum daha da kritiktir. İlkokul düzeyinde kullanılan dil yapıları ve kelime bilgisi en temel düzeydedir. $\mathrm{Bu}$ gruplara giren öğretmenler İngilizcede sayılar, renkler, eşyalar gibi basit kelimeleri öğretmekte ve dolayısıyla dil kullanımları bu temel düzey ile sınırlandırılmaktadır. Bu durumda, okul dışında yabancı dili kullanmayan bir öğretmen, yabancı dil öğrenmenin doğası olarak kullanmadığı ya da az kullandığı bilgileri unutabilmekte veya hatırlamakta zorlanmaktadır. Özellikle zaman ve tecrübe açısından düşünüldügünde, uzun yıllar ilkokul kademesinde çalışmış bir öğretmenin yabancı dil yeterliliği giderek körelebilmektedir. İngilizce öğretmenlerinin mesleklerinde yaşadıkları diğer iş yükleri ve tükenmişlikler ile dil alanında da köreldiklerini hissetmeleri meslekten artık keyif alamamalarına ve mutsuz olmalarına neden olabilmektedir. Ne yazık ki mutsuz öğretmen demek; mutsuz öğrenciler, mutsuz sınıflar demektir ve dolayısiyla mutsuz toplum demektir.

Bir öğretmenin mesleği boyunca en önemli görevlerinden birisi kendisini sürekli olarak geliştirmesi ve her an mesleği ile ilgili yenilikler peşinde koşmasıdır. Bunu yakalamak öğretmenin mesleki doyumluluğunu arttıracağ 1 gibi öğrenme ve öğretme sürecinin niteliğini de olumlu anlamda etkileyecektir.

Millî Eğitim Bakanlığı (2017) Öğretmenlik Mesleği Genel Yeterlikleri raporunda öğretmen ve niteliklerinin önemine şu şekilde vurgu yapılmıştır: 
"Öğretmenlerin yeterlikleri, mesleği etkili ve verimli olarak yürütmek için gerekli bilgi, beceri ve tutumlar olarak tanımlanmaktadır. Ĕgitimde planlanan hedeflere varmak, bu süreci yöneten ögrretmenlerin yeterlikleri ile paraleldir. Ĕger ki yenilikler ögretmenler tarafindan öğrenme sürecine aktarlmazsa hedeflere ulaşmak da güçleşecektir. Bu nedenle ögrencilerin başarısı ve geliş̧imleri, öğretmenlerin nitelikleri doğrultusunda artmaktadır. Bu durum hızlı değişimlere tanık olan günümüzde, ögretmenlerin kendilerini ve yeterliklerini gelişstirmelerine yönelik teşvik için oldukça önem arz etmektedir."

\section{Çalışmanın Önemi}

1739 numaralı Milli Eğitim Temel Kanunu'na (1973) göre öğretmenlik mesleği genel kültür, pedagojik formasyon ve özel alan bilgisi yeterliliğine sahip olmayı gerektirmektedir. Öğretmenin alan bilgisi ve bu konudaki yeterliğinin öneminden dolayı, alanda yapılan bazı çalışmalar vardır. Demirel (1989) Türk ve yabancı öğretmenlerin idealde göstermeleri gereken yeterlikler ile gerçekte gösterdikleri yeterlikler arasında nasıl bir fark olduğunu araştırmış, Türk öğretmenlerin konuşma becerilerinde kendilerinde bazı yetersizlikler gördüğü bulgusuna ulaşmıştır. Buna bağlı olarak Türk öğretmenlerin bu yetersizliği sınıf içerisinde anadil kullanımına ağırlık vererek yansıttıkları ortaya çıkmıştır. Ayrıca Türk öğretmenlerin daha çok dilin kurallarını öğretmeye çalışırken yabancı öğretmenlerin dil kullanımını öğreten çalışmalar yaptığı bulunmuştur.

Güven ve Çakır (2012) yaptıkları çalışmada, ilköğretim İngilizce öğretmenlerinin öz yeterlik inançlarını incelemişlerdir. Çalışmada İngilizce öğretmenlerinin öz yeterlik inançlarını çeşitli değişkenlere göre inceleyen araştırmacılar, ilköğretim kademesinde görevli İngilizce öğretmenlerinin öz yeterlik inançlarının mezun olunan fakülteye göre değiştiğini; İngilizce Öğretmenliği mezunu öğretmenlerin öz yeterlik inançlarının, İngiliz Dili ve Edebiyatı bölümünden mezun olan öğretmenlere göre daha yüksek olduğu sonucuna ulaşmişlardır.

Kararmaz ve Arslan'1n (2014) ilköğretim İngilizce öğretmenlerinin öğretmenlik mesleği özel alan yeterliklerine ilişkin algılarının çeşitli değişkenlere göre incelendiği çalışmalarında, İngilizce öğretmenlerinin öğretmenlik mesleği özel alan yeterliklerine ilişkin yeterlik algılarının oldukça yüksek olduğu bulunmuştur. Kararmaz ve Arslan'ın (2014) elde ettiği diğer bulgulara göre ise öğretmenlerin çoğu Dil Becerilerini Geliştirme yeterlik alanında kendilerini yeterli görürlerken öğrencilerin konuşma ve dinleme becerilerini 
geliştirebilmelerine ilişkin yeterlik algıları, yazma ve okuma becerilerini geliştirebileceklerine olan algılarından daha düşüktür.

Zengin ve Radmard (2019) tarafindan ilköğretim kurumlarında görev yapan İngilizce öğretmenlerinin mesleki ve iletişim yeterliklerine yönelik algıların incelendiği çalışmada, İngilizce öğretmenlerinin dil öğretimindeki alan yeterlikleri ile bunları sınıf içi süreçlere aktarma ve eğitim faaliyetlerinde kullanabilme arasında bir ilişki olduğu bulunmuştur. Zengin ve Radmard (2019) çalışmalarındaki bulgulara dayanarak yabancı dil öğretmenleri için dil öğretimi ile ilgili hizmet içi eğitim faaliyetlerine yönelik çalışmalar yapılabileceğini önermektedir.

Bahsedilen örneklerden de anlaşılacağ üzere, öğretmenlerin dil yeterliğinde kendilerini iyi düzeyde konumlandırdığ 1 sonucuna ulaşan çalışmalar olduğu kadar, öğretmenlerin bu konuda çeşitli sıkıntılar yaşadığ 1 ve bu durumun derslerini de etkilediği sonucuna ulaşan araştırmalar da bulunmaktadır. Araştırma konusu ile ilgili yapılan alanyazın tarama çalışmasında ise özellikle ilkokul İngilizce öğretmenleri ve onların meslekte ilerledikçe dil yeterliklerinde meydana gelen değişimleri inceleyen sınırlı sayıda çalışma olduğu görülmüştür. Türkiye'deki çalışmalar genel olarak mesleki yeterliklere ve öğrenciye belli dil stratejilerini kazandırma ve geliştirmeye yönelik yeterlikler çerçevesinde gerçekleştirilmiştir.

Diğer yandan öğretmenler eğitim programlarının en önemli uygulayıc1larındandır. Öğretmenlerin mesleki yeterlikleri öğrencilere kazandırılmak istenen bilgi, beceri, tutum ve değerlerle doğrudan ilgilidir. Çünkü öğretmenlerin kendileri ile ilgili mesleki öz-yeterlik algıları eğitim öğretim etkinliklerinin niteliğini doğrudan etkileyebilmektedir. Bundan dolayı öğretmenlerin alanlarındaki yeterliklerine yönelik farkındalık kazanmaları eğitim programları açısından da oldukça önem taşımaktadır.

\section{Çalışmanın Amacı}

$\mathrm{Bu}$ araştırma ilkokul İngilizce öğretmenlerinin kendi yabancı dil yeterlikleri hakkındaki görüşlerini incelemeyi amaçlamaktadır. Bu genel amaç doğrultusunda aşağıdaki sorulara yanıt aranmıştır:

İlkokul İngilizce öğretmenlerinin;

1. Mesleğe başladıktan sonra kendilerinin yabancı dil yeterlikleri,

2. Ders verdikleri yaş grubu ya da kademenin yabancı dil yeterliklerine etkisi, 
3. Okul dışında yabancı dil gelişimleri için yaptıkları çalışmalar,

4. Okul dışındaki yabancı dil gelişim faaliyetlerinin öğretim etkinliklerine etkisi,

5. İlkokul kademesindeki çalışma süresinin yabancı dil yeterliklerine etkisi hakkındaki görüşleri nelerdir?

\section{Yöntem}

\section{Araştırma Modeli}

İlkokul İngilizce öğretmenlerinin kendi yabancı dil yeterlikleri hakkındaki görüşlerini belirlemeyi amaçlayan bu çalışma bir karma yöntem araştırmasıdır. Karma yöntem araştırması; araştırmacının veri topladığı ve analiz ettiği, bulguları dahil ettiği ve tek bir çalışmada veya araştırma programında nitel ve nicel yaklaşım veya yöntemleri kullanarak çıkarımlarda bulunduğu bir araştırma olarak tanımlanmıştır (Creswell ve Plano-Clark, 2018).

\section{Çalışma Grubu}

Araştırmanın çalışma grubunu 2019-2020 eğitim öğretim y1lında Türkiye'nin çeşitli bölgelerinde görev yapan 117 ilkokul İngilizce öğretmeni oluşturmaktadır. Araştırmanın katılımcıları belirlenirken hazırlanan anket formu öğretmenlerle sosyal medyadaki gruplar aracılığı ile paylaşılmış ve gönüllü katılım esas alınmıştır. Araştırmaya 55 farklı ilden öğretmen katılım göstermiş ve katılımın en çok olduğu iller İstanbul ve Ankara olmuştur. Katılımcı öğretmenlerin \%90.8'i kadın, \%9.2'si erkek öğretmenlerden oluşmaktadır. Araştırmaya katılan kadın öğretmenlerin erkek öğretmenlerden sayıca fazla olmasının nedeni olarak ilkokullarda görevli kadın öğretmen sayısının (167.959) erkek öğretmen sayısına (104.770) göre daha fazla olması düşünülmektedir (MEB, 2020). Görev yaptıkları kurum türüne göre ise, katılımcı öğretmenlerin \%86.6'sı devlet okulunda görev yaparken \%14.4'ü özel okullarda çalışmaktadır. Bu durumun nedeni olarak ise yine devlet okullarında görevli öğretmen sayısının (275.733) özel okullarda görevli öğretmen sayısına (33.514) göre fazla olması düşünülmektedir (MEB, 2020). Çalışmaya katılan öğretmenlerin büyük bir çoğunluğunu (\%35.3) 0-4 yıl arası mesleki deneyime sahip olan öğretmenler oluştururken onları 5-10 yıl arası (\%31.9) mesleki deneyime sahip öğretmenler takip etmektedir. Öğretmenlerden 8'i (\%6.7) 16-20 y1l arası mesleki deneyime sahipken 6'sı (\%5) ise 20 ve üzerinde mesleki deneyime sahiptir.

\section{Veri Toplama Araçları}

Araştırmada veri toplama aracı olarak araştırmacılar tarafindan 
geliştirilen "İlkokul İngilizce Öğretmenlerinin İngilizce Diline Yönelik Yeterlikleri" isimli anket kullanılmıştır. Anketin kapsam geçerliğini sağlamak için uzman görüşlerinden yararlanılır (Büyüköztürk, Çakmak, Akgün, Karadeniz ve Demirel, 2019). Uygulanan bu anket formunun geçerliğini sağlamak için de hazırlanan sorular Eğitim Bilimleri ve İngilizce Öğretmenliği bölümünden iki uzmanın görüşleri alınarak yeniden düzenlenmiştir. Hazırlanan "İlkokul İngilizce Öğretmenlerinin İngilizce Diline Yönelik Yeterlikleri” isimli anketteki sorular aşağıdaki gibidir:

1. Mesleğinize başlamadan önce ve başladıktan sonra dil yeterliğinizde bir fark görüyor musunuz? Eğer cevabınız evet ise, nasıl bir fark görüyorsunuz? Lütfen açıklayınız.

2. Ders verdiğiniz yaş grubu/kademenin dil yeterliğinizde bir etkisinin olduğunu düşünüyor musunuz? Neden?

3. Okul dışında yabancı dilinizi kullanabilme imkânınız var mı? Cevabınız evet ise bu durumun öğretiminizi nasıl etkilediğini düşünüyorsunuz? Cevabınız hayır ise bu durumun öğretiminizi etkilediğini düşünüyor musunuz?

4. Dil becerilerinizdeki gelişimi devam ettirmek adına neler yapıyorsunuz?

5. Uzun y1llar ilkokul kademesinde dil dersi vermenin ya da verecek olmanın sizin dil becerinizde değişimlere yol açacağını/açtığııı düşünüyorsunuz?

\section{Veri Toplanması ve Analizi}

Veriler Google Forms aracılığıyla sosyal medyadaki gruplarla paylaşılarak katılımcılara gönderilmiş ve gönüllü şekilde yanıt veren katılımcıların cevapları değerlendirilmiştir. Verilerin çözümlenmesinde SPSS 24 paket programı kullanılmış ve bulgular tablolar hâlinde sunulmuştur.

\section{Bulgular}

\section{İlkokul İngilizce Öğretmenlerinin Mesleğe Başladıktan Sonra Yabancı Dil Öz Yeterliklerine Yönelik Görüşleri}

Araştırmaya katılan ilkokul İngilizce öğretmenlerinin mesleklerine başladıktan sonra dildeki yeterliklerine yönelik görüşleri Tablo 1'de verilmiştir. 
Tablo 1. İlkokul İngilizce Öğretmenlerinin Mesleğe Başladıktan Sonra Dil Yeterliklerindeki Farkl1lıklar

\begin{tabular}{llll}
\hline Tema & Kodlar & f & $\%$ \\
\hline Öğretmenlerin Mesleğe Başladıktan Sonra Dil & Evet & 108 & 92.3 \\
Yeterliklerinde Farklılaşma Durumu & Hayır & 9 & 7.7 \\
& Toplam & 117 & 100 \\
\hline
\end{tabular}

Tablo 1'de "Mesleğinize başlamadan önce ve mesleğinize başladıktan sonra dil yeterliğinizde bir fark görüyor musunuz?" sorusuna öğretmenlerin büyük bir çoğunluğu (\%92.3) fark gördüğünü belirtmiştir. Araştırmaya katılan öğretmenlerin sadece \%7.7'si dil yeterliklerinde mesleğe başladıktan sonra fark görmemektedir.

Araştırmaya katılan ilkokul İngilizce öğretmenlerinin mesleklerine başladıktan sonra dildeki yeterliklerindeki farkın türü Tablo 2'de verilmiştir.

Tablo 2. İlkokul İngilizce Öğretmenlerinin Mesleğe Başladıktan Sonra Dil Yeterliklerindeki Farkın Türü

\begin{tabular}{llll}
\hline Tema & Kodlar & f & \% \\
\hline Öğretmenlerin Mesleğe & Olumsuz & 78 & 72.2 \\
Başladıktan Sonra Dil & Olumlu & 28 & 25.9 \\
Yeterliklerindeki Farkın Türü & Hem Olumlu Hem Olumsuz & 2 & 1.9 \\
\cline { 2 - 5 } & Toplam & 108 & 100 \\
\hline
\end{tabular}

Tablo 2'de görüldüğg̈ üzere, mesleğe başladıktan sonra dil yeterliklerinde fark olduğunu düşünen öğretmenlerin sadece \%25.9'u bu farkın olumlu yönde olduğunu belirtirken geri kalan katılımcıların \%72.2'si farkın olumsuz yönde olduğunu ifade etmiştir. Katılımcılardan K(29) ve K(67) kodlu öğretmenlerin görüşleri şöyledir: "Dil kullanımı azaldığı için ciddi anlamda yenilenme ihtiyacı hissediyorum.” K(29), “Meslek tozlandırdı.” K(67).

Dil öğretiminde iletişimin önemini vurgulayan bir öğretmen ise dil yeterliğindeki durumunu şu şekilde ifade etmiştir: "Mesleğe başladıktan sonra hep aynı iletişim kalıplarını kullandiğımı fark ettim. Önemli olan ögrrenciyle iletişime geçebilmek ve bildikleri kalıplara cevap verebiliyorlar sadece. Ve bir yabancı ile konuşmadığım için aniden cevap verme, spontane bir diyalogu sürdürme becerilerimin azaldı̆̆ını hissediyorum.” K(110).

Diğer yandan dil yeterliklerinde olumlu gelişmeler yaşadıklarını belirten öğretmenler, bu gelişmenin özellikle konuşma becerilerinde olduğunu ve günlük konuşma dilinde daha akıcı hale geldiklerini söylemişlerdir. Örneğin katılımcılardan K(40) kodlu öğretmenin cevabı şu şekildedir: 
"Evet, elbette fark var ki bunun olumlu yönde olduğunu düşünüyorum. Özellikle dili daha rahat kullanabilme ve speaking konusunda geliştiğimin farkındayım açıkçası. Tabii bunda özel bir kurumda çalışmanın ve kullandı̆̆ımız sistemin payı büyük. Kendimizi geliştirmek ve gelişime açık olmak durumundayız, birbirini takip eden bir döngü söz konusu. Kendinizi güncellemek durumundasınız, gelişimi fark ettikçe de bu durum sizi şevklendiriyor." K(40).

\section{İlkokul İngilizce Öğretmenleri Ders Verdikleri Kademenin Yabancı Dil Yeterliklerindeki Etkisi}

Araştırmaya katılan ilkokul İngilize öğretmenlerinin ders verdikleri yaş grubunun dildeki yeterliklerine yönelik etkisi hakkındaki görüşleri Tablo 3 'te verilmiştir.

Tablo 3. İlkokul İngilizce Öğretmenlerinin Ders Verdikleri Yaş Grubu/Kademenin Dil Yeterliklerine Etkisi

\begin{tabular}{llll}
\hline Temalar & Kodlar & f & $\mathbf{\%}$ \\
\hline Öğretmenlerin Ders Verdikleri Yaş & Etkiliyor & 86 & 73.5 \\
Grubu/Kademenin Dil Yeterliklerine & Etkilemiyor & 31 & 26.5 \\
\cline { 2 - 4 } Etki Durumu & Toplam & 117 & 100 \\
\hline
\end{tabular}

Araştırmaya katılan öğretmenlerin $\% 73.5$ 'i ders verdikleri kademenin yabancı dil yeterliklerinde etkisinin olduğunu düşünürken geri kalanlar (\%26.5) ise herhangi bir etkisi olduğunu düşünmemektedir.

Araştırmaya katılan ilkokul İngilizee öğretmenlerinin ders verdikleri yaş grubunun dildeki yeterliklerine yönelik etkisinin türü hakkındaki görüşleri Tablo 4'te verilmiştir.

Tablo 4. İlkokul İngilizce Öğretmenlerinin Ders Verdikleri Yaş Grubu/Kademenin Dil Yeterliklerine Etki Türü

\begin{tabular}{llll}
\hline Temalar & Kodlar & f & \% \\
\hline Öğretmenlerin Ders Verdikleri Yaş & Olumsuz & 65 & 85.5 \\
Grubu/Kademenin Dil Yeterliklerine & Olumlu & 11 & 14.5 \\
\cline { 2 - 4 } Etki Türü & Toplam & 76 & 100 \\
\hline
\end{tabular}

Tablo 4'te "Ders verdiğiniz yaş grubu/kademenin dil yeterliğinizde bir etkisi olduğunu düşünüyor musunuz?" sorusuna etkisi olduğu düşünen öğretmenlerin \%85.5'i bu etkinin olumsuz olduğundan bahsetmektedir. Katılımc1 öğretmenlerin büyük bir çoğunluğu dil yeterliğindeki gelişimin öğretmenin kendi çabalarıyla olacağını söylemiştir. Örneğin K(14) kodlu öğretmen, öğretmenlerin okul dışı çaba göstermeleri gerektiğine şu sözlerle dikkat çekmiştir: 
"Neyle ilgileniyorsan o kadar oluyorsun... İlkögretim seviyesinde hello goodbye'yla seneleri öldürmemek gerek. Kitap okumak, gazete takip etmek gerek. Bunun için ben BBC, English Central gibi uygulamalarl kullaniyorum aktif olarak bunun dışında muhakkak bir haber kanalının bir iki haberini okumaya öncelik veririm." $\mathrm{K}(14)$.

Benzer şekilde K(31) kodlu öğretmen ise aşağıdaki ifadelerini kullanmıştır: "Dil yeterliliğimi etkileyen okul dışında yabancı dille olan uğraşımdır. Ögrencilerimin yaşının ve dil yeterliliklerinin az olması benim dil yeterliliğimin azalacağı anlamina gelmez." K(31).

Diğer yandan, ilkokul kademesinin dil yeterliklerinde olumlu etkiye sahip olduğunu düşünen öğretmenler, öğrenci seviyesine inebilmek için dillerini uyarlamak durumunda kaldıklarını dolayısıyla ilkokul kademesinde daha uzmanlaştıklarını belirtmişlerdir. Bu düşünceye yönelik bazı cevaplar şu şekildedir: "Yeni bir şey öğrenmiyorum ama her yıl ayn konuları daha iyi anlattığımı düşünüyorum.” K(114), "Dil yeterliliği önemli değil önemli olan seviyelere inebilmek." K(11), "Evet, temelden başllyoruz ve öğretirken daha iyi öğreniyorum.” $\mathrm{K}(103)$. Öğretmenlerden bir tanesi ise ders verilen kademenin değil çevrenin öğretmenin dil yeterliğinde etkisi olduğunu düşünerek, şu şekilde bir cevap vermiştir: "Düşünmüyorum sadece yaşanılan yere öğrenci ilgilerine ve velilerinde İngilizceye ilgili olduğu yerlerde dil yeterliliği oluyor ben ilkokul özel okulda ikinci sinuflarla daha iyiydim şimdi ortaokuldayım ama daha geriledi." (K1)

\section{İlkokul İngilizce Öğretmenlerinin Okul Dışında Yabancı Dil Gelişimleri İçin Yaptıkları Çalışmalar}

Araştırmaya katılan ilkokul İngilizce öğretmenlerinin dersleri dışında gerçekleştirdikleri yabancı dil faaliyetleri Tablo 5'te verilmiştir.

Araştırmaya katılan ilkokul İngilizce öğretmenlerinin büyük bir çoğunluğu günlük hayatta İngilizceyi yabancı dizi ve film izleyerek geliştirdiklerini belirtmişlerdir. Öğretmenler ayrıca dil gelişimlerini ilerletmek adına yabancı dizi ve filmleri İngilizce altyazı veya altyazısız İngilizce olarak izlemeyi tercih ettiklerini de eklemişlerdir. Öğretmenlerin \%23.3'ü ise okuma faaliyetlerine ağırlık verdiklerini; roman ve kitapları İngilizce orijinal dilinden okumayı, İngilizce kaynaklı araştırmalara dayalı makaleler ve bilimsel yazıları okuduklarını ifade etmişlerdir. Katılımcı öğretmenlerin \%10’u ise İngilizce yayın yapan kanalları, İngilizce öğrenenler için içerik hazırlayan web sitelerini ve 
benzer uygulamaları sosyal medya aracılı̆̆ ile takip ederek, bu sayede özellikle okuma ve dinleme becerilerini canlı tutmayı hedeflediklerini söylemişlerdir.

Tablo 5. İlkokul İngilizce Öğretmenlerinin Ders Dışı Gerçekleştirdikleri Yabanc1 Dil Faaliyetleri

\begin{tabular}{lll}
\hline Faaliyetler & f & $\mathbf{\%}$ \\
\hline Dizi/Film İzleme & 63 & 33.3 \\
Kitap/Dergi/Makale Okuma & 44 & 23.3 \\
Sosyal Medyada Yabancı Kanalları Takip Etme & 19 & 10.1 \\
Podcast Dinleme & 13 & 6.9 \\
Yabancı Dil Sınavlarına Hazırlanma (YDS, IELTS) & 12 & 6.3 \\
Herhangi Bir Faaliyette Bulunmama & 9 & 4.8 \\
Yabancı Kişilerle İletişim Kurma & 9 & 4.8 \\
Çeviri Yapma & 8 & 4.2 \\
Seminer ve Konferanslara Katılma & 8 & 4.2 \\
Proje Geliştirme & 4 & 2.1 \\
\hline Toplam & 189 & 100 \\
\hline
\end{tabular}

Bir katılımcı ise İngilizceyi hayatına entegre ettiğini ifade etmiştir. Diğer yandan araştırmaya katılan öğretmenlerin yaklaşı $\% 5$ 'i ders dışında İngilizce adına herhangi bir faaliyette bulunmadıklarını belirtmişlerdir. Bunun nedeni olarak bir öğretmen zamanının kalmadığını belirtirken K(104) kodlu öğretmen ise hangi etkinliklerde bulunması konusunda karasızlık yaşadığını şu sözler ile ifade etmiştir: "Yapmak istiyorum ama bir türlü yararlı olacak ne karar veremiyorum.” K(104). Okul dışında İngilizce gelişimi için faaliyet göstermeyen katılımcılardan K(93) kodlu öğretmenin ise şu cevabı oldukça ilginçtir: "Hiçbir şey yapmıyorum. İngilizceye katlanamıyorum." K(93).

\section{İlkokul İngilizce Öğretmenlerinin Okul Dışındaki Yabancı Dil Gelişim Faaliyetlerinin Derslerine Etkisi}

Araştırmaya katılan ilkokul İngilizce öğretmenlerinin okul dışında yabancı dil kullanma imkanları Tablo 6'da verilmiştir.

Tablo 6. İlkokul İngilizce Öğretmenlerinin Okul Dışında Yabancı Dil Kullanma İmkanları

\begin{tabular}{llll}
\hline Temalar & Kodlar & f & \% \\
\hline Öğretmenlerin Okul Dişıında & Yok & 83 & 70.9 \\
Yapanc1 Dil Kullanma & Var & 34 & 29.1 \\
\cline { 2 - 4 } İmkanları & Toplam & 117 & 100 \\
\hline
\end{tabular}

Tablo 6' dan anlaşılacağ 1 üzere araştırmaya katılan öğretmenlerin büyük bir çoğunluğu (\%70.9) okul dışında yabancı dillerini kullanabilmek için bir imkân bulamamaktadır. Kullanabilme imkanını sağlayan öğretmenlerden 
çoğu ise kendi çabalarıyla bu durumu oluşturduklarını ve bir önceki alt problemin bulgularına benzer olarak dizi, film veya uygulamalar ile yabanc1 dillerini diri tutmaya çalıştıklarını söylemişlerdir. İmkân bulamayan katılımcılardan K(19) ve K(49) kodlu öğretmenler ise kendileri için yabancı dillerini kullanabilecekleri ortamlar olması dilediğini şu sözlerle ifade etmişlerdir: "Pek fazla yok. Ama olsa çok güzel olabilir olumlu anlamda etkileyebilirdi (öğretimini)." K(19), "Çoğu zaman yok. Ama şu sıralar online bir hizmet içi eğitime katıldım. Çok faydasını görüyorum. Keşke sürekli böyle firsatlar sunulsa." $\mathrm{K}(49)$.

İlkokul İngilizce öğretmenlerinin okul dışında yabancı dil kullanmalarının öğretimlerini hangi yönde etkilediğine dair görüşleri Tablo 7'de gösterilmiştir.

Tablo 7. İlkokul İngilizce Öğretmenlerinin Okul Dış1 Yabancı Dil Kullanma İmkanları Olmasının Öğretimlerine Etki Durumları

\begin{tabular}{llll}
\hline Temalar & Kodlar & f & \% \\
\hline Öğretmenlerin Okul Dışı & Olumlu Etki & 18 & 52.9 \\
Yabancı Dil Kullanma & Etkinin Hangi Yönde Olduğunu Belirtmeyenler & 13 & 38.2 \\
İmkanları Olmasının Öğ- & Herhangi Bir Etkisi Olduğunu Düşünmeyenler & 3 & 8.8 \\
retimlerine Etki & Olumsuz Etki & 0 & 0 \\
\cline { 2 - 5 } Durumu & Toplam & 34 & 100 \\
\hline
\end{tabular}

Araştırmaya katılan ve okul dışında yabancı dil kullanan öğretmenlerin \%52.9'u bu etkinin olumlu olduğunu düşünürken olumsuz etkilediğini düşünen öğretmen olmamıştır. Olumlu etkisi olduğunu düşünen katılımcılar bu sayede daha fazla pratik yaptıklarını ve dildeki özgüvenlerinin arttığını söylemişlerdir. Öğretmenlerin yaklaşık \%9'u ise okul dışı dil faaliyetlerinin derslerine veya öğretimlerine herhangi bir etkisi olmadığını ifade etmiştir. Bu öğretmenler ders dışında kullandıkları yabancı dilin, sınıf içi dilden daha üst düzeyde olduğunu ve derslerine katkı sağlamadığını söylerken ayrıca sınıftaki dilin zaten basit olduğu için dışarıdaki faaliyetlerden etkilenmeyeceğini eklemişlerdir.

Tablo 8. İlkokul İngilizce Öğretmenlerinin Okul Dışı Yabancı Dil Kullanma İmkanları Olmamasının Öğretimlerine Etki Durumları

\begin{tabular}{llll}
\hline Temalar & Kodlar & f & \% \\
\hline Öğretmenlerin Okul Dışı & Etkinin Hangi Yönde Olduğunu Belirtmeyenler & 44 & 53 \\
Yabancı Dil Kullanma & Olumsuz Etki & 20 & 24.1 \\
İmkanları Olmamasının & Herhangi Bir Etkisi Olduğunu Düşünmeyenler & 19 & 22.9 \\
Öğretimlerine Etki & Olumlu Etki & 0 & 0 \\
\cline { 2 - 5 } Durumu & Toplam & 83 & 100 \\
\hline
\end{tabular}


İlkokul İngilizce öğretmenlerinin okul dışında yabancı dil kullanmamalarının öğretimlerini hangi yönde etkilediğine dair görüşleri Tablo 8'de gösterilmiştir. Okul dışı yabancı dil kullanma imkânı olmayan öğretmenlerden \%24'ü bu durumun öğretimlerini olumsuz etkilediğini düşünürken hiçbir öğretmen etkinin olumlu yönde olduğunu belirtmemiştir. Öğretmenlerin yaklaşık \%23'ü ise okul dışında yabancı dil kullanmamalarının öğretimlerine herhangi bir etkisi olduğunu düşünmemektedir. Bu grup içerisindeki diğer öğretmenler ise etkinin hangi yönde olduğunu ifade etmemişlerdir.

\section{İlkokul İngilizce Öğretmenlerinin, İlkokul Kademesinde Çalışma Süre- lerinin Yabancı Dil Yeterliklerine Etkisi}

Araştırmaya katılan ilkokul İngilizce öğretmenlerinin bu kademede uzun yıllar çalışmanın/çalışacak olmanın dil yeterliklerine etkisi hakkındaki görüşleri Tablo 9' da gösterilmiştir.

Tablo 9. İlkokul İngilizce Öğretmenlerinin İlkokulda Çalışma Sürelerinin Dil Yeterliklerine Etkisi Hakkındaki Düşünceleri

\begin{tabular}{llll}
\hline Temalar & Kodlar & f & \% \\
\hline Öğretmenlerin Uzun Yıllar & Olumsuz & 101 & 86.3 \\
İlkokulda Çalışmanın Dil & Olumlu & 13 & 11.1 \\
Yeterliklerine Etkisi Hakkındaki & Herhangi Bir Değişimin Olmaması & 3 & 2.6 \\
\cline { 2 - 5 } Düşünceleri & Toplam & 117 & 100 \\
\hline
\end{tabular}

Araştırmaya katılan ilkokul İngilizce öğretmenlerinin \%86.3'ü eğer bu kademede uzun yıllar devam ederlerse yabancı dil yeterliklerinde ciddi bir olumsuz etki yaşayacaklarını belirtmiştir. Bu görüşe sahip olan öğretmenlerin ortak düşünceleri yabancı dilde gerileme, unutma ve körelme yaşayacaklarıdır. $\mathrm{Bu}$ durumun öğretimlerinde mutsuzluğa ve isteksizliğe yol açacağına inanmaktadırlar. Örneğin K(27) kodlu öğretmenin cevabı şu şekildedir: "Giderek daha da uzaklaşacağımı ve soğuyacağımı düşünüyorum.” K(27). Benzer şekilde $\mathrm{K}(57)$ kodlu öğretmen de düşüncelerini şu sözlerle ifade etmiştir: "Net köreltiyor, başka bir şeye yol açmıyor. Ne dönüt anlamında tatmin oluyorum ne de kendime katkl sağlayabiliyorum." K(57). Körelmenin getirdiği umutsuzluğu ise katılımcılardan $\mathrm{K}(81)$ kodlu öğretmen çok net şu şekilde açıklamıştır: "Yıllar sonra artık tamamen Ingilizce konuşamaz olacağımı düşünüyorum.” (K81).

Bazı öğretmenler ise körelmenin sebebini okulun bulunduğu bölgeye bağlamış olup sosyo-ekonomik şartların ve refah düzeyinin artmasının öğrenci ihtiyaçlarını ve öğretmenden beklentileri değiş̧ireceğine inandığını belirtmiştir. Bu durumun ülkemizde yaşanan bir sorun olduğuna dikkat çeken 
katılımc1 öğretmenlerden K(19) ise şu yorumu yapmıştır: "Olumsuz. Dil becerilerimi köreltecek. Çünkü burası Türkiye. Yabancı bir ülkede olsam böyle düşünmezdim." (K19)

Olumsuz etkisi olduğunu düşünen öğretmenler genellikle kelime bilgisinde ciddi bir azalma yaşadıklarını ve önceden bildikleri birçok dil yapı ve bilgisini zamanla hatırlayamadıklarını söylemişlerdir. Mesleğe yeni başlamış öğretmenlerinde olumsuz etkisi olduğunu düşünmeleri ise ilginçtir ve bu durumla ilgili katılımcılardan $\mathrm{K}(3)$ kodlu öğretmen durumu şu sözlerle belirtmiştir: "1 yıldır çalışıyorum fakat yine de gerilediğimi hissediyorum." (K3).

Ayrıca öğretmenlerin büyük bir çoğunluğu ders dışında dilin kullanılacağı aktiviteler yapılmazsa körelmenin daha da hızlı şekilde oluşacağını savunmuşlardır. Diğer yandan katılımcıların \%11.1'i değişimin olumlu yönde olduğunu belirtmiştir. Öğretmenlerin bahsettikleri bu olumlu değişim genelde branş ve yaş düzeyi bazında profesyonelleşmede yoğunlaşmaktadır. Katılımcı öğretmenler ayrıca küçüklere dili sevdirme ve bu yaş grubu için gereken materyalleri hazırlamada uzmanlaştıklarını da ifade etmişlerdir. Öğretmenlerden sadece üçü ne olumlu ne de olumsuz bir etkinin oluşacağını düşünmektedir.

\section{Sonuç ve Tartışma}

Araştırmadan elde edilen bulgulara göre, katılımcı öğretmenlerin büyük bir çoğunluğunun mesleğine başladıktan sonra dil yeterliklerinde fark gördüğü ortaya çıkmıştır. Öğretmenlerden önemli bir kısmının bu farkın olumsuz yönde olduğunu belirtmesi ise elde edilen diğer bir sonuçtur. Araştırmaya katılan öğretmenlerin yabancı dil yeterliklerinde körelme ve gerileme yaşadıkları ve bu durumu ilkokulda görev yapmalarına bağladıkları görülmektedir. Öğretmenlerin yabancı dil yeterliklerinde yaşadıkları körelmeye yönelik bu bulgu Nunan'ın (2003) araştırmasının bulgularına benzer özellikler taşımaktadır. Nunan çalışmasını Asya-Pasifik bölgesindeki öğretmenler ile gerçekleştirmiş ve öğretmenlerin birçoğunun başarılı bir yabancı dil edinimi için öğrencilerinin ihtiyacı olan gerekli zengin dil yeterliliğine sahip olmadığı sonucuna ulaşmıştır. Nunan, bu durumun erken yaşta dil öğrenimi için kritik olduğunu belirtmiş ve öğretmenlerin kendi dil becerilerini geliştirebilecekleri adımların atılmasını önermiştir. Ayrıca Orafi ve Borg'un (2009) üç öğretmen ile Libya'da yürüttükleri çalışmalarında, öğretmenlerin yeterli dil becerisine sahip olmadıkları için iletişimsel aktivitelerin anlaşılması ve uygulanmasında sorunlar yaşadıkları ortaya çıkmıştır. Gerçekleştirilen bu çalışmada ise ilkokul İngilizce öğretmenleri sürekli aynı dil kalıplarını kullanarak yabancı dili sınırlı 
düzeyde konuşmaktan yakınmaktadırlar.

Araştırmanın sonuçlarına göre öğretmenlerin büyük bir çoğunluğu ders verdikleri kademenin dil yeterliklerine etkisi olduğunu düşünürken -bu etkinin genel olarak olumsuz yönde olduğunu düşündükleri görülmektedir. Öğretmenler ders verdikleri kademenin etkisini sürekli aynı dili kullanmaktan, sadece belli kelime ve konularda daha fazla uzmanlaşıp -dil becerilerinin sınırlı düzeyde kalması olarak açıklamaktadırlar. Ayrıca araştırmada, öğretmenlerin birçoğunun ilkokulda çalışmanın kendi dil yeterliklerinde körelmeye sebep olduğunu düşündükleri ortaya çıkmaktadır. Araştırmanın bu sonucu İngilizce öğretmenlerinin dil yeterliği ile yapılan çeşitli çalışmaların sonucu ile paralellik göstermektedir. Örneğin Chacón (2005) öğretmen etkinliği ve dil yeterliği ile ilgili yürüttüğü çalışmasında, araştırmasına katılan öğretmenlerden \%50'sinin özellikle konuşma becerilerinde önemli eksikler yaşadıklarını ve dildeki yetersizliğin öğretmenlerin ders işleyişlerini etkilediği sonucuna ulaşmıştır. Butler (2004) Koreli, Tayvanlı ve Japon ilkokul İngilizce öğretmenleri ile gerçekleştirdiği çalışmasında öğretmenlerden İngilizce dil yeterliklerini ve ilkokul seviyesinde İngilizce öğretmek için gereken minimum İngilizce seviyesini belirlemelerini istemiştir. Öğretmenler konuşma ve yazma becerilerinin dinleme ve okuma becerilerine göre yetersiz olduğunu, İngilizce dil yeterlikleri ile öğretimleri için sahip olmaları gereken seviye arasında önemli bir boşluk olduğunu belirtmişlerdir. Berry (1990, akt; Eslami ve Fatahi, 2008) Polonyalı İngilizce öğretmenleri ile gerçekleştirdiği çalışmasında öğretmenlerden metodoloji, dil öğretme teorisi ve dil gelişimi seçenekleri arasında en çok ihtiyaç duyulan şekilde sıralama yapmalarını istemiştir. Öğretmenler, dil gelişimi alanını en çok ihtiyaç duydukları alan olarak ilk sırada seçmişlerdir.

İngilizce öğretmenlerinin yaşadıkları bu sorunlar sınıf ortamına olumsuz olarak yansımakta ve öğretmenler hedef dilin kullanımını gerektiren etkinliklerden kaçınmaktadır. Öğretmenler ayrıca uzun yıllar ilkokul kademesinde devam edilmesinin körelmeyi arttıracağını, mesleki yetersizlik ve isteksizliğe yol açacağını düşünmektedirler. $\mathrm{Bu}$ durumun ayrıca öğretmenlerde motivasyon eksikliği yaratacağı ve hem kendileri hem de öğrencileri için mutsuz bir öğrenme öğretme ortamı oluşturacağı söylenebilir.

Katılımcı öğretmenlerin büyük bir çoğunluğu ders dişı yabancı dil faaliyetlerini çalıştıkları kurum veya bakanlıktan bağımsız olarak kendi çabaları ile yürüttüklerini ifade etmişlerdir. Ayrıca öğretmenlerin mesleklerinde geçirdikleri yıl ile dil yeterliklerindeki değişime dair bir fark gözlenmemiştir, 
çünkü henüz mesleğinin başında olan birçok öğretmenin yabancı dilde ilkokul kademesinde çalışmaya bağlı olarak gerilemeler yaşadıklarını ve gelecek yıllarda bunun artacağına inandıkları ortaya çıkmıştır.

İlkokul İngilizce öğretmenlerinin yabancı dillerini günlük hayatta kullanma olanakları ise oldukça kısıtlıdır ve öğretmenlerin büyük bir çoğunluğu öğrettikleri dilin dışarıda kullanım olarak karşılığını görememektedir. Öğretmenlerin sadece okulda belli bir seviye ile işlenen derslerde, limitli dil kullanımına maruz kalmaları ve dillerini canlı tutacak imkanlara sahip olmamaları ise alan açısından incelenmesi gereken önemli bir sonuçtur. Çünkü ne yazık ki ülkemizde İngilizce öğretmen adaylarının bile bazıları üniversite eğitimlerine kadar ana dili İngilizce olan kişilerle sohbet edip dil gelişimlerine katkıda bulunma şansına sahip olamamaktadırlar, bu nedenle öncelikle öğreteceği dilde kendi sorunlarını halletmiş yabancı dil öğretmenlerine ihtiyaç duyulmaktadır (Çetinavcı ve Yavuz, 2010).

Araştırma genel olarak devlet okullarında çalışan öğretmenlerle yürütülmüş olup özel okullarda görev alan öğretmenler de yabancı dil yeterliklerinde olumsuz farklılıklar olduğunu belirtmişlerdir. Genel olarak bakıldığında ilköğretim düzeyinde görev yapan İngilizce öğretmenlerinin dil yeterliklerine yönelik görüşlerinin büyük ölçüde olumsuz olduğu görülmektedir. Bu sonuçlar Arslan, Mirici ve Öz'ün (2019) İngilizce öğretmenlerinin mesleki gelişim için nelere ihtiyaç duyduklarını araştırdıkları çalışmanın sonuçlarıyla benzerlik göstermektedir. Çünkü çalışmanın sonuçlarına göre İngilizce öğretmenleri mesleki gelişim aktivitelerinde yer almak için kendi konuşma becerilerini geliştirmeye ihtiyaç duymaktadırlar. Bu durumun ilkokul İngilizce öğretmenlerinin ve doğal olarak ders verdikleri ilkokul öğrencilerinin motivasyon ve dil öğrenmedeki niteliğini etkileyebileceğini söylemek mümkündür. Yenen ve Dursun (2019) çalışmalarında İngilizce öğretmenlerinin ders anlatış biçimlerini incelemişler ve öğretmenlerin İngilizceyi basit düzeydeki yönergeler d1şında fazlaca kullanmadıkları, özellikle dinleme ve konuşma becerilerini gerektiren aktivitelere sıklıkla yer vermedikleri sonucuna ulaşmışlardır. Görüldüğü gibi araştırmalardan elde edilen sonuçlar ilkokul İngilizce öğretmenlerinin dillerindeki yeterliklerinin öğretimlerini de etkilediğini ortaya koymaktadır. Bu nedenle öğretmenlerin meslekleri boyunca kendilerini geliştirmelerini ve öğrettikleri alanla ilgili yeterlikler konusunda uzmanlaşmalarını sağlayacak etkinliklere yönlendirilmeleri beklenmektedir (Genç, 2010). Aksi halde var olan sorunun daha da artabileceği öngörülmektedir. 


\section{Öneriler}

Araştırmadan elde edilen bulgulara göre geliştirilen önerilere bu bölümde verilmiştir. Geliştirilen öneriler aşağıdaki gibidir:

1. Öğretmenler uzun y1llar ilkokul kademesinde çalışmak yerine belli bir yıldan sonra kademe değişikliğine yönlendirilebilirler.

2. Bundan sonraki çalışmalarda konu ile ilgili nicel ve karma yöntemler ile araştırmalar yapılabilir.

\section{Kaynakça}

Arslan, S., Mirici, İ. ve Öz, H. (2019). In-service training needs of EFL teachers in non-formal education settings. Selçuk Üniversitesi Edebiyat Fakültesi Dergisi, 42, 223-244.

Butler, Y. G. (2004). What level of English proficiency do elementary school teachers need to attain to teach EFL? Case studies from Korea, Taiwan and Japan. TESOL Quarterly, 38(2), 245-278.

Büyüköztürk, Ş., Çakmak, K. E., Akgün, E. Ö., Karadeniz, Ş. ve Demirel, F. (2019). Ĕgitimde bilimsel araştırma yöntemleri (26. bask1). Ankara: Pegem Akademi.

Chacón, C. (2005). Teachers' perceived efficacy among English as a foreign language teachers in middle schools in Venezuela. Teaching and Teacher Education, 21(3), 257-272.

Creswell, J. W. ve Plano-Clark, V. L. (2018). Karma yöntem araştırmalarının doğası. (Y. Dede ve S. B. Demir, Çev.), Karma yöntem araştırmaları tasarımı ve yürütülmesi (3. baskı) içinde (s.1-21) (Y. Dede ve S. B. Demir, Çev. Ed.). Ankara: Anı Yayıncılık. (Orijinal çalışma basım tarihi 2011).

Çetinavc1, U. ve Yavuz, A. (2010). Language proficiency level of English language teacher trainees in Turkey. The International Journal of Research in Teacher Education, 1(4), 26-54.

Demirel, Ö. (1989). Yabancı dil öğretmenlerinin yeterlikleri. Hacettepe Üniversitesi Ĕgitim Fakültesi Dergisi, 5(5), 133-163.

Özen, N. E., Alpaslan, B. İ., Çağli, A., Sancak, M., Dizman, O. ve David, A. (2014). Türkiye'deki devlet okullarında ingilizce dilinin ögretimine ilişkin ulusal ihtiyaç analizi. Ankara: British Council.

https://www.tepav.org.tr/upload/files/1399388519-1.Turkiyedeki_Dev-

let_Okullarinda_Ingilizce_Dilinin_Ogrenimine_Iliskin_Ulusal_Ihtiyac_Analizi.pdf

Eslami, Z. R. ve Fatahi, A. (2008). Teachers' sense of self-efficacy, English proficiency, and instructional strategies: A study of nonnative EFL teachers in Iran. Tesl-Ej, 11(4), 1-19.

Galaczi, E., Nye, A., Poulter, M. ve Allen, H. (2018). Teacher professional development. Cambridge, United Kingdom. https://www.cambridgeenglish.org/Images/539683-perspectives-teacher-professional-development.pdf

Genç, G. (2010). İngilizce öğretmenlerinin mesleki gelişim sürecinin önünde algıladıkları başlıca engeller: Malatya ili örneği. Elektronik Sosyal Bilimler Dergisi, 9(31), 103-117. 
Güven, S. ve Çakır, Ö. (2012). A study on primary school English teachers' self-efficacy beliefs. Eğitim ve Bilim, 37(163), 43-52.

Karacaoğlu, Ö. C. (2008). Öğretmenlerin yeterlilik algıları. Yüzüncü Yıl Üniversitesi Eğitim Fakültesi Dergisi, 5(1), 70-97.

Kararmaz, S. ve Arslan, A. (2014). İlköğretim İngilizce öğretmenlerinin öğretmenlik mesleği özel alan yeterliklerine ilişkin algılarının belirlenmesi. Uşak Üniversitesi Sosyal Bilimler Dergisi, 7(4), 203-232.

Milli Eğitim Bakanlığı. (1973). Milli eğitim temel kanunu. https://www.mevzuat.gov.tr/MevzuatMetin/1.5.1739.pdf

Milli Eğitim Bakanlığı. (2015). İlköğretim özel alan yeterlikleri. https://oygm.meb.gov.tr/meb_iys_dosyalar/2017_11/06160113_2-YYretmen_Yeterlikleri_KitabY_ingilizce_YYretmeni_Yzel_alan_yeterlikleri_ilkYYretim_parYa_5.pdf

Milli Eğitim Bakanlığı. (2017). Öğretmenlik mesleği genel yeterlikleri. http://oygm.meb.gov.tr/meb_iys_dosyalar/2017_12/11115355_YYRETMENLYK_MESLEYY_GENEL_YETERLYKLËERY.pdf

Milli Eğitim Bakā̄lı̆̆1. (2020). Milli eğitim istatistikleri örgün eğitim 2019-2020. http://sgb.meb.gov.tr/meb_iys_dosyalar/2020_09/04144812_meb_istatistikleri_orgun_egitim_2019_2020.pdf

Nunan, D. (2003). The impact of English as a global language on educational policies and practices in the Asia-Pacific region. TESOL Quarterly, 37(4), 589-613.

Orafi, S. M. S. ve Borg, S. (2009). Intentions and realities in implementing communicative curriculum reform. System, 37(2), 243-253.

Songbatumis, A. M. (2017). Challenges in teaching English faced by English teachers at MTsN Taliwang, Indonesia. Journal of Foreign Language Teaching and Learning, 2(2), 54-67.

Yenen, E. ve Dursun, F. (2019). İngilizce öğretmenlerinin öğretim süreci öz-yeterlikleri ve sınıf ortamına yansımaları. Mersin Üniversitesi Eğitim Fakültesi Dergisi, 15(2), 607-627.

Yeşilyurt, E. (2011). Öğretmen adaylarının öğretmenlik mesleğinin genel yeterliklerine yönelik algıları. Türk Ë̆itim Bilimleri Dergisi, 9(21), 71-100.

Yeşilyurt, E. (2013). Öğretmen adaylarının öğretmen öz-yeterlik algıları. Elektronik Sosyal Bilimler Dergisi, 12(45), 88-104.

Y1lmaz, C. (2011). Teachers' perceptions of self-efficacy, English proficency and instructional strategies. Social Behavior and Personality: an international journal, 39(1), 91-100.

Zengin, D. Ö. T. ve Radmard, S. (2019). İlköğretim kurumlarında görev yapan İngilizce öğretmenlerinin mesleki ve iletişim yeterliliklerine yönelik algılarının analizi. Academy Journal of Educational Sciences, 3(1), 42-63. 